\title{
Preliminary observations on possible pathogen spill-over from Apis mellifera to Apis cerana
}

\author{
Eva Forsgren ${ }^{1}$, Shi $\mathrm{WeI}^{2}$, Ding GuIling ${ }^{2}$, Liu Zhiguang ${ }^{2}$, Toan Van Tran ${ }^{3}$, \\ Phuong Thi TANG ${ }^{3}$, Tuan Anh TruOnG ${ }^{3}$, Tam Quyet DinH ${ }^{3}$, Ingemar FrIEs ${ }^{1}$ \\ ${ }^{1}$ Department of Ecology, Swedish University of Agricultural Sciences, PO Box 7044, SE-750 07, Uppsala, Sweden \\ ${ }^{2}$ Bee Research Institute, Chinese Academy of Agricultural Sciences (CAAS), Xiang Shan, 100093, Beijing, China \\ ${ }^{3}$ Bee Research and Development Centre, No. 19 truc Khe, Dong Da Hanoi, Vietnam
}

Received 15 November 2013 - Revised 31 July 2014 - Accepted 22 September 2014

\begin{abstract}
Populations of Apis mellifera and Apis cerana in China and Vietnam were surveyed in order to study possible pathogen spill-over from European to Asian honeybees. This is the first survey of the prevalence of honeybee pathogens in apiaries in Vietnam, including pathogen prevalence in wild A. cerana colonies never in contact with $A$. mellifera . The bee samples were assayed for eight honeybee viruses: deformed wing virus (DWV); black queen cell virus (BQCV); sac brood virus (SBV); acute bee paralysis virus (ABPV); Kashmir bee virus (KBV); Israeli acute paralysis virus (IAPV); chronic bee paralysis virus (CBPV); and slow bee paralysis virus (SBPV), for two gut parasites (Nosema ssp.) and for the causative agent for European foulbrood (Melissococcus plutonius ). The Vietnamese samples were assayed for Acarapis woodi infestation. No clear evidence of unique inter-specific transmission of virus infections between the two honeybee species was found. However, in wild A. cerana colonies, the only virus infection detected was DWV. With findings of IAPV infections in Chinese samples of $A$. cerana colonies in contact with $A$. mellifera, inter-specific transmission of IAPV cannot be ruled out. BQCV was the most prevalent virus in managed colonies irrespective of bee species. We did not detect the causative agent of European foulbrood, M. plutonius in wild or isolated colonies of A. cerana in Vietnam or China; however, low incidence of this pathogen was found in the Asian host species when in contact with its European sister species. No evidence for the presence of $A$. wood $i$ was found in the Vietnamese samples.
\end{abstract}

\section{Apis mellifera / Apis cerana / virus infections / Nosema ssp / Acarapis woodi / Melissococcus plutonius}

\section{INTRODUCTION}

Throughout the world, the European honeybee (Apis mellifera) is plagued by two parasites whose original host was the Asian honeybee, Apis cerana. Undoubtedly, the exoparasitic mite Varroa destructor (Anderson and Trueman 2000) and associated virus infections are the major threats to beekeeping causing colony losses all over the world (reviewed in Rosenkranz et al. 2010). Another parasite, the intracellular microsporidium Nosema ceranae, was first

Corresponding author: E. Forsgren,

eva.forsgren@slu.se

Manuscript editor: Yves Le Conte described from A. cerana (Fries et al. 1996) but was found in 2005 as naturally occurring infections in European honeybees both in Europe and in Asia (Higes et al. 2006; Huang et al. 2007) and is now detected throughout the world (Klee et al. 2007). The impact of this parasite has been reported to be severe (Higes et al. 2009), but the colony level impact may be different in different climates (reviewed in Fries 2010). Moreover, neither $N$. ceranae nor its sister species Nosema apis has a competitive advantage within bees infected with both species (Forsgren and Fries 2010).

Diseases of Asian honeybee species are largely an unexplored field. Compared to the wealth of information available on honeybee pathology from the European honeybee A. mellifera, our 
knowledge of the Asian honeybee species, including the managed $A$. cerana, is truly rudimentary (reviewed in Fries 2011). Understanding more of the pathology of Asian honeybee species is important for several reasons. With an increased awareness of the importance of pollination and biodiversity, conservation of Asian honeybee species becomes essential. Moreover, understanding how pathogens and parasites interact within and between species may be instrumental for preventing unexpected colony losses. As already seen with $V$. destructor infestations and $N$. ceranae infections, the impact of one pathogen in one honeybee species may be different in another closely related host system. Thus, more research on pathogens from Asian honeybee species is warranted to prevent disease-induced losses in these bees. It is also imperative to identify possible threats from inter-specific transmission of pathogens. Inter-specific transmission of pathogens between different host systems is currently viewed as one of the most important sources of biodiversity loss and may lead to severe hostparasite interactions (Deredec and Courchamp 2003). Today, apiculture with A. mellifera occurs throughout most of the natural distribution area of A. cerana and dominates the honey production also in Asia. For example, over $80 \%$ of the honey production in Vietnam is harvested from colonies of $A$. mellifera (Chinh and Tam 2004). In China, A. cerana colonies represented $90 \%$ of managed honeybee colonies in 1949, but the number was reduced to $26.6 \%$ in 1991 ( $\mathrm{Li} 1991)$. Although the two honeybee species mentioned often occur within flight distance of one another, little is known regarding possible pathogen spill-over from A. mellifera to A. cerana . Data from Japan suggest possible inter-specific transmission from A. mellifera to A. cerana for at least one virus infection (IAPV) (Kojima et al. 2011a, b). A phylogenetic analysis of DWV isolates from A. mellifera, Apis florea and Apis dorsata hosts in China actually suggests that DWV may have moved from $A$. mellifera to $A$. florea and A. dorsata (Zhang et al. 2012). The documented transmission route via pollen collection, coupled with low host specificity for most RNA virus infections found in A. mellifera, strongly indicates that pollinators sharing foraging range will be exposed to the same virus infections via pollen collection (Singh et al. 2010). With the current understanding of the importance of viral infections in European honeybees, it could be vital to understand if some of these infections pose a threat to $A$. cerana. Six different virus infections so far have been identified from Asian honeybees using serological tools: apis iridescent virus (AIV), black queen cell virus (BQCV), deformed wing virus (DWV), Kashmir bee virus (KBV) and Thai and Chinese sac brood virus (TSBV, CSBV) (Allen and Ball 1996). The latter may be strains of the same virus as RNA-viruses in honeybees may be very variable (Forsgren et al. 2009). Using molecular tools, four different virus infections were found in samples of $A$. cerana in Japan (DWV, BQCV, IAPV and SBV) (Kojima et al. 2011a, b). A Chinese survey using molecular assays detected the same infections but, in addition, also CBPV and ABPV (Ai et al. 2012). In Korean samples of $A$. cerana, five different virus infections were present (BQCV, SBV, DWV, KBV and CBPV) ( Choe et al. 2012). It remains unclear if some viral infections already detected in A. cerana may in fact represent inter-specific pathogen transmission because of the widespread distribution of A. mellifera. Undoubtedly, more virus infections will be detected as molecular tools become increasingly available.

Possibly, other pests and pathogens, such as tracheal mites (Acarapis woodi) found in A. mellifera and causing occasional severe damage in A. cerana populations (Abrol 2000; Muzaffar and Ahmad 1991; Kojima et al. 2011a, b), may pose an additional threat to Asian honeybees. When this parasite first occurred in A. mellifera in North America, the effects from the infestations were devastating, leading to large colony losses (Otis and Scott-Dupree 1992). European foulbrood (EFB), caused by the bacterium Melissococcus plutonius, a gram-positive lanceolate cocci (Bailey 1956) has been reported to cause considerable damage in managed colonies of $A$. cerana (Chinh 1998). In the first report of EFB in Asian honeybees, the source of infection was assumed to be European honeybee colonies introduced from the USA (Diwan et al. 1971). This isolate of M. plutonius from A. cerana could, however, 
be clearly distinguished from isolates from A. mellifera using serological typing (Bailey 1974). Thus, M. plutonius is probably an endemic infection in Asian honeybees. Nevertheless, different isolates of $M$. plutonius exhibit different levels of virulence (Charriere et al. 2011) and inter-specific transfer of EFB may be a threat to honeybee health.

The overall aim of this study was to investigate if the pathogen prevalence differs in A. cerana colonies with or without contact to A. mellifera and to shed light on possible pathogen spill-over from A. mellifera to A. cerana.

\section{MATERIALS AND METHODS}

\subsection{Sample collection}

We sampled honeybee colonies in different locations in the south and north of Vietnam (Tien Giang, Hoa Binh, Dien Bien, Con Dao, Son La) and in five regions of China (Xinjiang, Beijing, Fujian, Liaoning and Guang Dong). All sampling was made during periods of active foraging for all colonies. A total of 58 A. mellifera colonies in 20 apiaries, 5 (12 colonies) in Vietnam and 15 (46 colonies) in China were sampled during 2011-2012 (Table I). Eight isolated A. cerana wild colonies that had never been in contact with
A. mellifera were sampled in the northwest of Vietnam (this category is labeled " $i$ " in Tables and Figures). In addition, a total of 20 managed $A$. cerana colonies located in 6 apiaries ( 3 apiaries/11 colonies in Vietnam and 3 apiaries/9 colonies in China) were sampled where the colonies had never been within flying distance of A. mellifera colonies (category "ii" in Tables and Figures). Finally, 42 A. ceranae colonies located in 16 apiaries (7 apiaries/14 colonies in Vietnam and 9 apiaries/28 colonies in China) were sampled where the distance to A. mellifera apiaries varied between $200 \mathrm{~m}$ and $2 \mathrm{~km}$ (category "iii" in Tables and Figures). In each apiary, 2-6 colonies were sampled with a minimum of 10 adult bees per colony.

Samples collected in China consisted of whole bees immediately frozen, transported and stored in $-80^{\circ} \mathrm{C}$ until analysed.

Samples collected in Vietnam for later virus analysis consisted of extracted midguts in tubes with RNAlater ${ }^{\circledR}$ in order to preserve RNA. Whole bees were sampled for $A$. woodi and M. plutonius assays. After sampling, the material was kept in room temperature for approximately 1 day, thereafter refrigerated for approximately 3-5 days and then frozen in $-80{ }^{\circ} \mathrm{C}$ until extracted. Extracted RNA was frozen in $-80{ }^{\circ} \mathrm{C}$ and extracted DNA in $-20{ }^{\circ} \mathrm{C}$ until processed.

Table I. Virus infections in wild and managed colonies of A. mellifera and A. cerana in Vietnam and China. The figures in the table indicate the proportion of colonies positive for the respective viruses.

\begin{tabular}{cllllllllll}
\hline & $\begin{array}{l}\text { Number } \\
\text { of colonies }\end{array}$ & $\begin{array}{l}\text { Number } \\
\text { of apiaries }\end{array}$ & DWV & ABPV & IAPV & KBV & BQCV & CBPV & SBV & SBPV \\
\hline $\begin{array}{l}\text { Vietnam } \\
\text { Managed } A m\end{array}$ & 12 & 5 & 0.75 & 0 & 0 & 0 & 1 & 0.67 & 0.42 & 0 \\
$\begin{array}{c}\text { i) Wild } \\
\text { colonies } A c\end{array}$ & 8 & - & 0.88 & 0 & 0 & 0 & 0 & 0 & 0 & 0 \\
$\begin{array}{c}\text { ii) Isolated, } \\
\text { managed } A c\end{array}$ & 11 & 3 & 1 & 0 & 0 & 0 & 0.27 & 0.18 & 1 & 0 \\
$\begin{array}{c}\text { iii) Mixed, } \\
\text { managed } A c\end{array}$ & 14 & 7 & 1 & 0 & 0 & 0 & 0.93 & 0.50 & 0.36 & 0 \\
$\begin{array}{c}\text { China } \\
\text { Managed } A m\end{array}$ & 46 & 15 & 0.74 & 0.15 & 0.24 & 0 & 0.93 & 0.37 & 0.61 & 0 \\
$\begin{array}{c}\text { ii) Isolated, } \\
\text { managed } A c\end{array}$ & 9 & 3 & 1 & 0.22 & 0 & 0 & 1 & 0 & 0 & 0 \\
$\begin{array}{c}\text { iii) Mixed, } \\
\text { managed } A c\end{array}$ & 28 & 9 & 0.64 & 0 & 0.04 & 0 & 1 & 0.18 & 0.29 & 0 \\
\hline
\end{tabular}




\subsection{RT-PCR detection of viruses}

Samples of adult bees were pooled in extraction bags, flash frozen in liquid nitrogen and ground manually. One hundred microliter of the resulting filtered extract was resuspended in $350 \mu \mathrm{L}$ of RLT buffer (RNeasy ${ }^{\text {TM }}$ Plant Mini Kit, QIAGEN). Total RNA was extracted using the RNeasy ${ }^{\mathrm{TM}}$ protocol (QIAGEN). Samples of pooled dissected midguts $(N=30)$ were ground in liquid nitrogen, resuspended in $350 \mu \mathrm{L}$ of RLT buffer and total RNA extracted using the same protocol as for the bees. Extracted RNA was stored at $-80{ }^{\circ} \mathrm{C}$ until processed.

Eight honeybee viruses: deformed wing virus (DWV); black queen cell virus (BQCV); sac brood virus (SBV); acute bee paralysis virus (ABPV); Kashmir bee virus (KBV); Israeli acute paralysis virus (IAPV); chronic bee paralysis virus (CBPV); and slow bee paralysis virus (SBPV) were screened on all pooled colony samples from both countries using the protocols from Locke et al. (2012). Briefly, for virus detection and quantification, RT-PCR assays were completed using iScript ${ }^{\mathrm{TM}}$ One-Step RT-PCR Kit with SYBR ${ }^{\circledR}$ Green (Bio-Rad). The single step RT-PCR assay was performed containing $5.8 \mu \mathrm{L}$ of nuclease-free $\mathrm{H}_{2} \mathrm{O}$, $10 \mu \mathrm{L} \mathrm{SYBR}{ }^{\circledR}$ Green master mix $(2 \times), 0.4 \mu \mathrm{L}$ of each primer (for primers, see Locke et al. 2012) and $0.4 \mu \mathrm{L}$ of enzyme. Three microliters of sample RNA was added and the final reaction volume adjusted to $20 \mu \mathrm{L}$. The amplification and data acquisition was carried out using either a Bio-Rad ${ }^{\circledR}$ Chromo4 ${ }^{\mathrm{TM}}$ (Vietnamese samples) or iQ5 $^{\mathrm{TM}}$ real-time PCR detection system (Chinese samples) under the following cycling condition: cDNA synthesis, $50{ }^{\circ} \mathrm{C}$ for $10 \mathrm{~min}$; reverse transcriptase inactivation, $95{ }^{\circ} \mathrm{C}$ for $5 \mathrm{~min}$; followed by PCR cycling (35 cycles of $95{ }^{\circ} \mathrm{C}$ for $10 \mathrm{~s}, 58{ }^{\circ} \mathrm{C}$ for $30 \mathrm{~s}$ ) The amplified product was confirmed by melt curve analysis from 55 to $95{ }^{\circ} \mathrm{C}$ in $0.5{ }^{\circ} \mathrm{C}$ increments. Recombinant DNA template was used as standards in every run. All real-time reactions (standards, unknown samples and controls) were performed in neighbouring wells on the sample plate.

\subsection{PCR detection of Nosema spp.}

Bees and dissected midguts were flash frozen and grinded as described above. One hundred microliters of the resulting bee extract or grinded midguts was subjected to extraction of total genomic DNA using standard methods according to the manufacturer's protocol (DNeasy ${ }^{\mathrm{TM}}$ Plant Mini Kit, QIAGEN). For automated purifications, a QIAcube ${ }^{\mathrm{TM}}$ (QIAGEN) instrument was used. The extracted DNA was eluted in $50 \mu \mathrm{L}$ elution buffer (QIAGEN) and frozen at $-20^{\circ} \mathrm{C}$ until processed.

The detection and identification of Nosema spp. was carried out using a previously published real-time PCR assay (Forsgren and Fries 2010). In brief, the real-time PCR reaction was performed using $10 \mu \mathrm{L}$ of SsoFast ${ }^{\mathrm{TM}}$ EvaGreen ${ }^{\circledR}$ Supermix (Bio-Rad), $0.4 \mu \mathrm{M}$ of each primer, $2 \mu \mathrm{L}$ of template and the final reaction volume adjusted to $20 \mu \mathrm{L}$ with nuclease-free water. The amplification and data acquisition was carried out using a Chromo $4^{\circledR}$ or an $\mathrm{iQ5}^{\mathrm{TM}}$ (Bio-Rad) real-time PCR machine under the following cycling condition: initial activation step, $95^{\circ} \mathrm{C}$ for 5 min, PCR cycling $\left(40\right.$ cycles of $94{ }^{\circ} \mathrm{C}$ for $30 \mathrm{~s}, 63^{\circ} \mathrm{C}$ for $30 \mathrm{~s}, 72{ }^{\circ} \mathrm{C}$ for $30 \mathrm{~s}$ ) including data collection The amplified products were confirmed using melting curve analysis. Each set of PCR assays comprised recombinant DNA templates of the $N$. apis and $N$. ceranae PCR fragments as positive controls and a non-template control containing water instead of DNA template.

\subsection{PCR detection of M. plutonius}

A real-time PCR assay by Roetschi et al. (2008), for monitoring EFB in honeybee colonies using samples of adult bees, was used for the detection of the causative agent of European foulbrood, M. plutonius. Briefly, bees were flash frozen and grinded as described above. One hundred microliters of the resulting bee extract was subjected to DNA extraction following the protocol for enzymatic lysis of gram-positive bacteria (DNeasy ${ }^{\mathrm{TM}}$ Blood \& Tissue Kit, QIAGEN). For automated purifications, a QIAcube ${ }^{\mathrm{TM}}$ (QIAGEN) instrument was used. The extracted DNA was eluted in $50 \mu \mathrm{L}$ elution buffer (QIAGEN) and frozen at $-20{ }^{\circ} \mathrm{C}$ until processed.

\subsection{PCR detection of $A$. woodi}

The detection of $A$. woodi in the Vietnamese samples was carried out using a PCR-based assay by Kojima et al. (2011a, b) with minor modifications. The Chinese samples were not assayed for $A$. woodi. In brief, a pooled sample of 32 bees were prepared for DNA extraction by removing the abdomen and the head of each bee using a clean scalpel, and placing the bee thoraxes into filter grinding bags (Neogen $\left.{ }^{\mathrm{TM}}\right)$. 
Nuclease-free water was added to the grinding bag at a rate of $0.5 \mathrm{~mL}$ buffer per bee. One millilitre of the lysate produced was centrifuged ( $3 \mathrm{~min}, 16,000 \mathrm{~g}$ ) and the pellet resuspended and extracted following the protocol for animal tissue, DNeasy ${ }^{\circledR}$ Blood and Tissue Kit (QIAGEN). The extracted DNA was eluted in $50 \mu \mathrm{L}$ elution buffer (QIAGEN) and frozen at $-20{ }^{\circ} \mathrm{C}$ until processed. The real-time PCR reaction was performed using $10 \mu \mathrm{L}$ of $\mathrm{iQ}^{\mathrm{TM}} \mathrm{SYBR}^{\circledR}$ Green Super mix (Bio$\mathrm{Rad}), 0.4 \mu \mathrm{M}$ of each primer, $2 \mu \mathrm{L}$ of template and the final reaction volume adjusted to $20 \mu \mathrm{L}$ with nucleasefree water. The amplification and data acquisition was carried out using a Chromo4 ${ }^{\circledR}$ (Bio-Rad) real-time PCR machine under the following cycling condition: initial activation step, $95^{\circ} \mathrm{C}$ for $5 \mathrm{~min}$, PCR cycling ( 35 cycles of $94{ }^{\circ} \mathrm{C}$ for $30 \mathrm{~s}, 58{ }^{\circ} \mathrm{C}$ for $30 \mathrm{~s}, 72{ }^{\circ} \mathrm{C}$ for $30 \mathrm{~s}$ ) including data collection The amplified products were confirmed using melting curve analysis. Each set of PCR assays comprised recombinant DNA templates of the $A$. woodi PCR fragments as well as total DNA from mites as positive controls and a non-template control containing water instead of DNA template.

\section{RESULTS}

\subsection{Virus infections in $A$. mellifera and $A$. cerana colonies in Vietnam and China}

We analysed the prevalence of eight honeybee viruses (DWV, ABPV, IAPV, KBV, BQCV, CBPV, SBV and SBPV) in 12 A. mellifera colonies in Vietnam and 46 A. mellifera colonies in China. The results are shown in Figure 1a and in Table II. Sampled bees from managed A. mellifera colonies in Vietnam were infected with four viruses: DWV (75\%), BQCV (100\%), CBPV (67\%) and SBV (42\%). No A. mellifera bees were found infected with ABPV, IAPV, KBV or SBPV in the Vietnamese survey. Sampled bees from managed $A$. mellifera colonies in China were infected with six viruses: DWV (74 \%), ABPV (15\%), IAPV (28\%), BQCV (98 \%), CBPV (37\%) and SBV (76\%). No $A$. mellifera bees were found infected with $\mathrm{KBV}$ or SBPV in the Chinese survey.

In addition, we analysed virus prevalence in a total of 33 A. cerana colonies in Vietnam and 37 A. cerana colonies in China. The A. cerana colonies are grouped as follows: i) wild colonies (from northwest Vietnam); ii) managed, but isolated colonies of A. cerana (no A. mellifera colonies within flying distance); and iii) managed colonies of $A$. cerana (within flying distance from A. mellifera colonies, mixed apiaries).

The results are presented in detail in Figure 1a and in Table I. In brief, bees from the wild colonies (i) were infected with one virus only, DWV (88\%), whereas the isolated, managed colonies (ii) were infected with DWV (100\%; Vietnam and China), ABPV (22\% in China), BQCV (27\% in Vietnam; $100 \%$ in China), CBPV (18\% in Vietnam), SBV (100\% in Vietnam). Bees from managed $A$. cerana colonies in mixed apiaries or apiaries within flying distance of $A$. mellifera colonies (iii) were infected with DWV (100\% in Vietnam; $64 \%$ in China), IAPV (4\% in China), BQCV (93\% in Vietnam; $100 \%$ in China), CBPV (50\% in Vietnam; $18 \%$ in China) and SBV (36\% in Vietnam; $29 \%$ in China). No A. cerana bees were found infected with ABPV, IAPV, KBV or SBPV in the Vietnamese survey. No $A$. cerana bees were found infected with KBV or SBPV in the Chinese survey.

CBPV was detected in managed A. cerana colonies from both China and Vietnam.

If we combine the prevalence data for all virus infections of the combined wild and isolated A. cerana group and compared to the A. cerana group in contact with $A$. mellifera, we find no significant difference (chi-square, $P>0.05$ ) except for $\mathrm{CBPV}$ where infections appear to be more prevalent in A. cerana colonies in contact with A. mellifera (chi-square, $P<0.05$ ). Regarding $\mathrm{BQCV}$ infections, the results are confusing. If we look at the Vietnamese samples only, the difference in BQCV infection is highly significant between the two groups (chi-square, $P<0.001$ ). However, all of the A. cerana colonies in China, not in contact with A. mellifera, were infected with CBPV making the combined data set non-significant.

\subsection{Nosema ssp. and M. plutonius infections in A. mellifera and A. cerana colonies in Vietnam and China}

The samples were DNA extracted and assayed for microsporidia, Nosema ssp. and the bacterium 

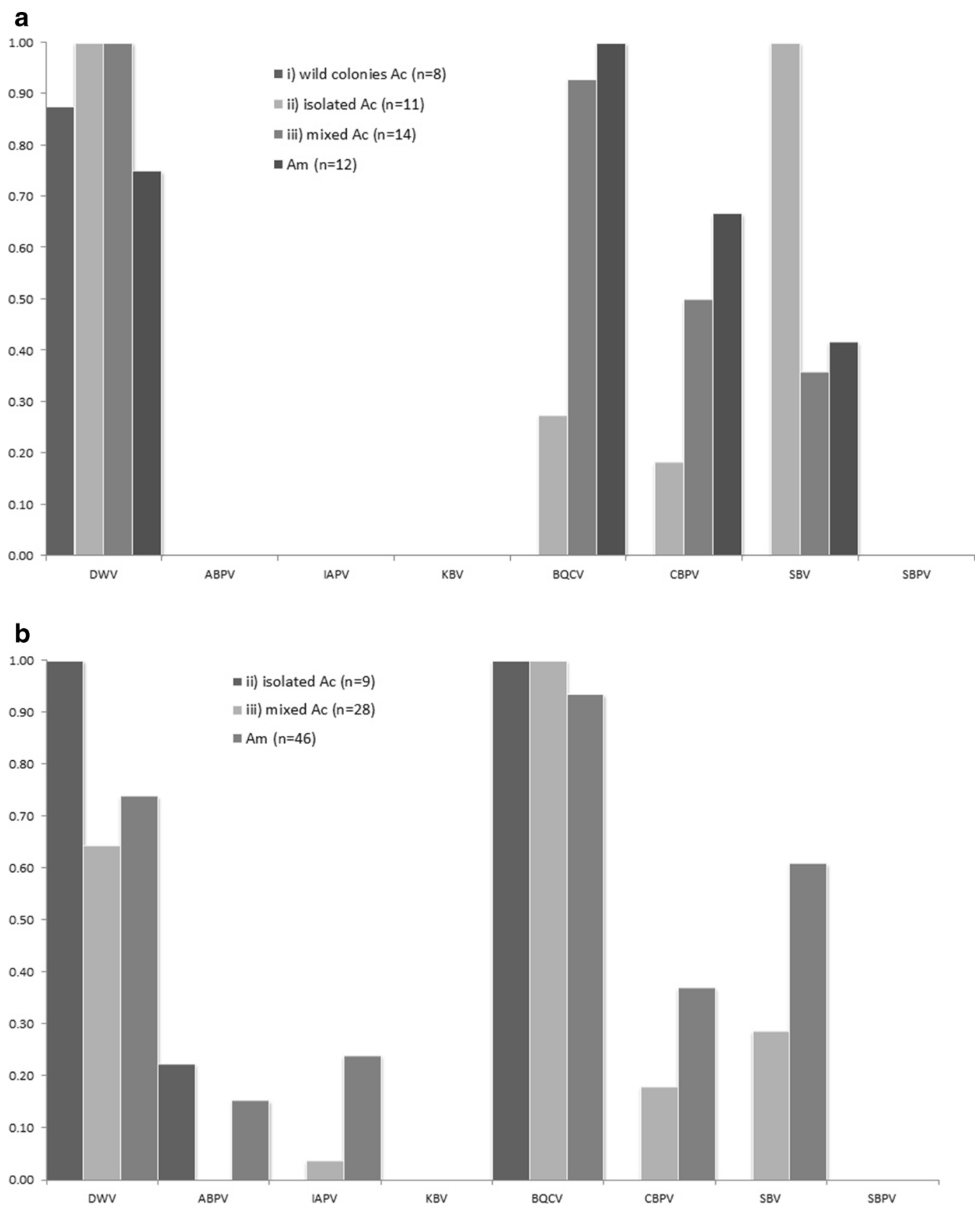

Figure 1. Virus infections in A. mellifera and A. cerana colonies in a Vietnam and $\mathbf{b}$ China presented as the proportion of colonies positive for the respective viruses.

M. plutonius, the causative agent of European foulbrood. For $A$. mellifera, there were eight colonies in Vietnam and 28 in China, whereas for A cerana , 28 Vietnamese and 20 Chinese colonies were assayed.
N. ceranae was detected in $88 \%$ of the investigated $A$. mellifera colonies in Vietnam and $64 \%$ of the $A$. mellifera colonies in China, as well as in $A$. cerana colonies of all categories in both 
Table II. Nosema ssp.and M. plutonius infections in colonies of A. mellifera and A. cerana in Vietnam and China. The figures in the table indicate the proportion of colonies positive for the respective pathogens.

\begin{tabular}{llllll}
\hline & $\begin{array}{l}\text { Number of } \\
\text { colonies }\end{array}$ & $\begin{array}{l}\text { Number of } \\
\text { apiaries }\end{array}$ & M. plutonius & N. ceranae & N. apis \\
\hline $\begin{array}{l}\text { Vietnam } \\
\text { Managed } A m\end{array}$ & 8 & 3 & 0.12 & 0.88 & 0 \\
i) Wild colonies $A c$ & 8 & - & 0 & 0.38 & 0 \\
ii) Isolated, managed $A c$ & 11 & 3 & 0 & 0.18 & 0 \\
iii) Mixed, managed $A c$ & 9 & 5 & 0.11 & 0.78 & 0 \\
China & & & & & 0 \\
Managed $A m$ & & & & 0.69 & 0 \\
ii) Isolated, managed $A c$ & 9 & 12 & 0.35 & 0.33 & 0 \\
iii) Mixed, managed $A c$ & 11 & 3 & 0 & 0.72 & 0 \\
\hline
\end{tabular}

countries (see Table II for details). No case of $N$. apis infection was detected in any of the samples.

M. plutonius was detected $15 \%$ in Vietnam and $32 \%$ in China of the assayed A. mellifera colonies, but was not detected in any of the assayed wild or isolated A. ceranae colonies, neither in Vietnam nor in China. However, in one of the assayed mixed apiaries in Vietnam (Tien Giang province), M. plutonius was detected in both A. cerana and A. mellifera colonies; and in China, M. plutonius was detected in one A. cerana colony within flying distance from A. mellifera colonies. Neither of these colonies showed clinical symptoms of disease. The detailed results are presented in Figure 2 and in Table I.

\subsection{Tracheal mite infestation in $A$. mellifera and $A$. cerana colonies in Vietnam}

Samples from Vietnam were DNA extracted and assayed for the presence of the tracheal mite, A. woodi. Bees from 25 colonies in $10 \mathrm{~A}$. cerana apiaries, 12 colonies in 5 A. mellifera apiaries and 9 wild A. cerana colonies were subjected to DNA extraction and assayed using PCR (Kojima et al. 2011a, b). None of the investigated samples proved to be positive for $A$. woodi .

\section{DISCUSSION}

We present data from a study of pathogen prevalence in A. mellifera and A. cerana beekeeping in China and Vietnam. This is, to our knowledge, the first survey of the prevalence of honeybee pathogens in apiaries in Vietnam, and, in addition, we present data on pathogen prevalence in wild $A$. cerana colonies never in contact with A. mellifera.

Although some of the presented results may indicate transmission of pathogens from A. mellifera to A. cerana, the evidence of unique inter-specific transmission of pathogens between A. mellifera and A. cerana is weak. However, there are some indications of increased pathogen pressure in $A$. cerana if they occur in contact with A. mellifera compared to isolated managed or wild colonies without contact with A. mellifera . For example, in the Chinese samples, five virus types (DWV, IAPV, BQCV, CBPV and SBV) were detected in $A$. cerana colonies within flying distance of, or mixed with, $A$. mellifera, whereas samples from isolated managed $A$. cerana colonies contained only three virus types (DWV, $\mathrm{ABPV}$ and BQCV; Figure 1a, b). The virus prevalence in Vietnam differed with all the assayed A. cerana apiaries containing the same four virus types (DWV, BQCV, CBPV and SBV) whether they were in contact with A. mellifera or not. However, it should be noted that samples from 


\section{a}

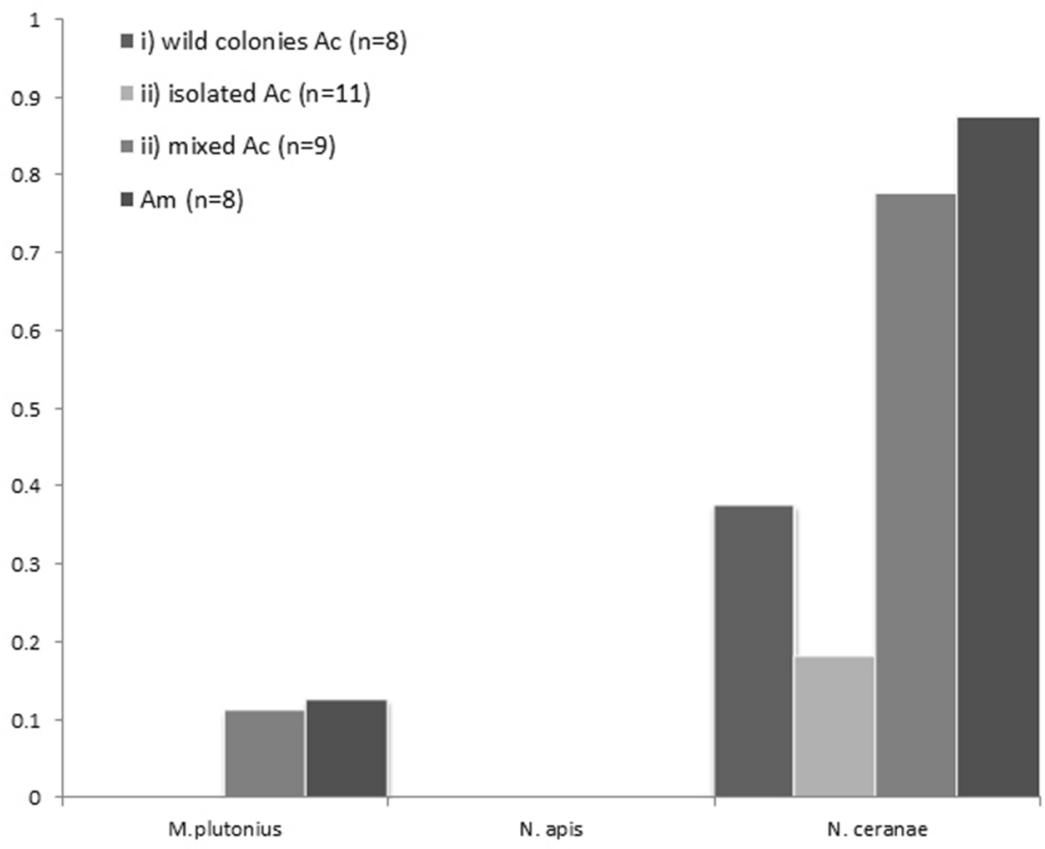

b

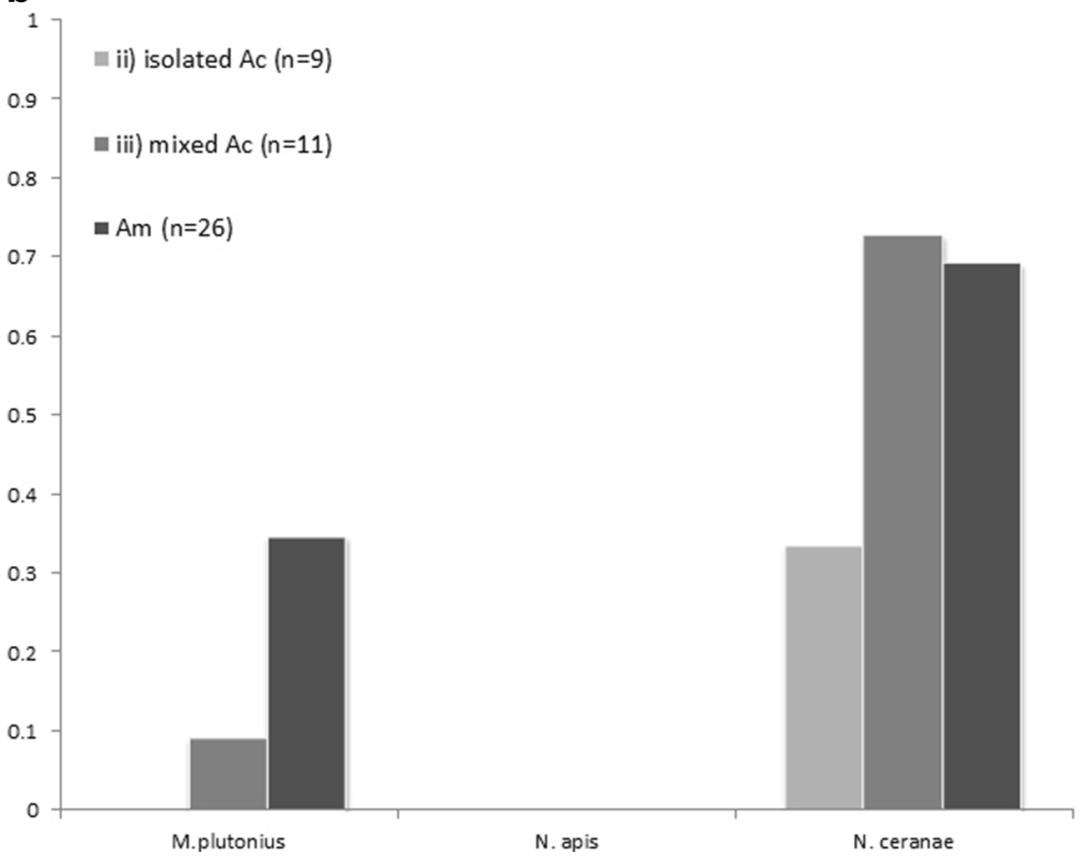

Figure 2. Nosema and EFB prevalence in A. mellifera and A. cerana colonies in a Vietnam and $\mathbf{b}$ China presented as the proportion of colonies positive for the respective pathogens. 
Vietnam consisted of dissected midguts; thus, the viral loads might differ from those obtained from the Chinese whole adult bee samples.

When disease incidence in wild and managed isolated colonies of A. cerana is compared, it appears that management per se increases disease prevalence for some infections but not for others (i.e. virus infections and EFB infections (brood disease) are more prevalent but data suggests no significant difference in $N$. ceranae prevalence, Table I). This is congruent with data from A. mellifera where brood disease is very low in free-living colonies and significantly higher in managed colonies (Goodwin et al. 1994; Hornitzky et al. 1996), whereas N. apis infections show little difference in incidence between managed and free-living colonies (Manning et al. 2007). Although the number of samples from wild colonies is low $(N=8)$, our data suggest that the negative impact of apiculture on disease prevalence is similar in both A. mellifera and A. cerana .

We find no clear evidence of unique interspecific transmission of virus infections between A. mellifera and A. cerana. In wild colonies, where contact with $A$. mellifera is highly unlikely, the only virus infection detected was DWV (Figure 1a). However, in isolated (but managed) colonies of $A$. cerana in Vietnam, we also find low prevalence of CBPV. These colonies were sampled on the isolated island Con Dao in southern Vietnam where A. mellifera was never introduced. Thus, CBPV probably is an endemic infection also in A. cerana . In China, we find IAPV in $A$. mellifera only in A. cerana colonies in contact with $A$. mellifera, whereas IAPV was not found at all in Vietnamese samples of either host species. These results are congruent with earlier findings of IAPV in China (Ai et al. 2012) and may indicate a spill-over effect from A. mellifera to A. cerana. It should be noted that the absence of IAPV in all the Vietnamese samples and in the A. cerana colonies in China without contact to $A$. mellifera could be circumstantial due to the low sample size and differences in the material sampled. However, in this case, interspecific transmission cannot be ruled out based on the Chinese results (Table I). In regional surveys for ABPV or the related IAPV in A. cerana, the infections are often not found (Li 1991; Choe et al. 2012) but may occur (Ai et al. 2012; Yanez et al. 2012). We found ABPV in isolated managed A. cerana colonies in China. This is contrary to the Chinese survey from Ai et al. (2012) where ABPV was not found in A. cerana. IAPV and ABPV are closely related viral infections and may be strains of the same virus species (de Miranda et al. 2010). Thus, it currently appears unclear if this virus complex is endemic to A. cerana or not, a topic which warrants further study. Of particular interest would be to increase the sample size of A. cerana, preferably from wild colonies in areas without contact to A. mellifera, and focus on pathogens where there is a potential spill-over effect based on the current study. If there is a genuine spill-over effect of pathogens from European honeybees to Asian honeybee spp., further introductions of $A$. mellifera into areas where this species is not already present could be unwise.

BQCV was the most prevalent virus in managed colonies irrespective of bee species and was also found in all of the investigated colonies in isolated A. cerana apiaries in Guangdong province in China. This is contrary to the result from Ai et al. (2012) where BQCV was only detected in one single colony of A. cerana. However, in Vietnam, the prevalence of BQCV in isolated apiaries was significantly lower than in A. cerana apiaries within flying distance to A. mellifera $\left(\mathrm{X}_{4}^{2}=14.99 ; P<0.01\right)$.

Heavy infestation of $A$. woodi was found in dead $A$. cerana japonica samples in Japan (Kojima et al. 2011a, b). The samples came from managed colonies with reported winter losses in the winter of 2009-2010. No evidence for the presence of $A$. woodi could be found in any of the samples in our study.

We find no evidence of the causative agent of European foulbrood, M. plutonius in wild or isolated colonies of $A$. cerana neither in Vietnam nor in China. We find a low incidence of this pathogen in the Asian host species when in contact with its European sister species. This suggests inter-specific transmission of this pathogen from A. mellifera to A. cerana. However, the incidence is low (see Table II), and when EFB was first diagnosed in A. cerana in 1971 (Diwan et al. 1971), serological typing suggested that the infection had not been introduced 
through contact with A. mellifera (Bailey 1974). The data presented here does not preclude $M$. plutonius being an endemic infection in Asian honeybees. However, inter-specific transfer of $M$. plutonius strain exhibiting different levels of virulence may still be a threat to Asian honeybees.

Although this study does not provide clear evidence for a unique inter-specific transmission or pathogen spill-over from managed $A$. mellifera colonies to $A$. cerana, the results indicate a higher pathogen pressure in managed $A$. cerana colonies when in contact with A. mellifera. Moreover, the data suggests that the pathogen prevalence in wild colonies of $A$. cerana is much lower compared to that of managed colonies, particularly for BQCV and SBV indicating that apiculture per se increases pathogen pressure also in A. cerana, at least for these two infections.

\section{ACKNOWLEDGMENTS}

This study had financial support from the Swedish International Development Agency (SIDA), the Bee Research and Development Center (BRDC), Hanoi, Vietnam, and the Apicultural Research Network of China (Project CARS-4). The authors would also like to thank Emilia Semberg and Assin Kelemeworki for the excellent technical assistance and Luo Yuexiong, Wang Dali, Yuan Chunying, Wang Shunhai and Liu Tianqi for the sampling assistance.

\section{OPEN ACCESS}

This article is distributed under the terms of the Creative Commons Attribution License which permits any use, distribution, and reproduction in any medium, provided the original author(s) and the source are credited.

Observations préliminaires sur une possible transmission de pathogènes d'Apis mellifera vers Apis cerana

Apidae / virus/ transmission / Nosema spp. / Acarapis woodi/ Melissococcus plutonius / Chine / Vietnam

Vorläufige Beobachtungen zu einer möglichen Erregerübertragung von Apis mellifera zu Apis cerana

Apis mellifera / Apis cerana / Virusinfektionen / Nosema ssp. / Acarapis woodi / Melissococcus plutonius

\section{REFERENCES}

Abrol, D.P. (2000) Beekeeping with Apis cerana in Jammu and Kashmir: present status and future prospects. Bee World 81, 149-152

Ai, H., Yan, X., Han, R. (2012) Occurrence and prevalence of seven bee viruses in Apis mellifera and Apis cerana apiaries in China. J. Invertebr. Pathol. 109, 160-164

Allen, M., Ball, B. (1996). World distribution of honey bee viruses. Bee World. 7, 141-162

Anderson, D.L., Trueman, J.W.H. (200). Varroa jacobsoni (Acari: Varroidae) is more than one species. Exp. Appl. Acarol. 24, 165-189

Bailey, L. (1956) Aetiology of European foulbrood; a disease of the larval honeybee. Nature. 178, 1130

Bailey, L. (1974) An unusual type of Streptococcus pluton from the Eastern hive bee. J. Invertebr. Pathol. 23, 246-247

Charriere, J.D., Kilchenmann, V., Rotshi, A. (2011) Virulence of different Melissococcus plutonius strains on larvae tested by an in vitro larval test; In Proceedings of the 42nd International Apicultural Congress. Buenos Aires 2011, 158

Chinh, H.P. (1998) Thai sac brood virus disease control in Vietnam. In: In: Proceedings of 4th Asian Apicultural Association International Conference, Katmandu, pp. 57-59

Chinh, H. P., Tam, Q. D. (2004). Honey quality for export. In: Proceedings of Apimondia Symposium, Hanoi, pp 27-31

Choe, S.E., Lien, T.K.N., Noh, J.H., Koh, H.B., Jean, Y.H., Kweon, C.H., Kang, S.W. (2012) Prevalence and distribution of six bee viruses in Korean Apis cerana populations. J. Invertebr. Pathol. 109, 330-333

Deredec, A., Courchamp, F. (2003) Extinction thresholds in host-parasite dynamics. Ann. Zool. Fennici 40, 115130

de Miranda, J.R., Cordoni, G., Budge, G. (2010) The acute bee paralysis virus-Kashmir bee virus-Israeli acute paralysis virus complex. J. Invertebr. Pathol. 103, S30-S47

Diwan, V.V., Kshirsag, K.K., Rao, A.V.R., Raghunat, D., Bhambure, C.S., Godbole, S.H. (1971) Occurrence of a new bacterial disease of Indian honeybees Apis indica. F Curr Sci 40, 196-197

Forsgren, E., Fries, I. (2010) Comparative virulence of Nosema ceranae and Nosema apis in individual European honey bees. Vet. Parasitol. 170, 212-217

Forsgren, E., de Miranda, J.R., Isaksson, M., Shi, W., Fries, I. (2009) Deformed wing virus associated with Tropilaelaps mercedesae infesting European honey bees (Apis mellifera). Exp. Appl. Acarol. 47, 87-97

Fries, I. (2010) Nosema ceranae in European honey bees (Apis mellifera ). J. Invertebr. Pathol. 103, S73-S79

Fries, I. (2011) Diseases of Asian honeybees. In: Hepurn, R., Radloff, S.E. (eds.) Asian honeybees, pp. 333-345. Springer, Heidelberg 
Fries, I., Feng, F., Silva, A., da Slemenda, S.B., Pieniazek, N.J. (1996) Nosema ceranae n. sp. (Microspora, Nosematidae), morphological and molecular characterization of a microsporidian parasite of the Asian honey bee Apis cerana (Hymenoptera, Apidae). Europ. J. Protistol 32, 356-365

Goodwin, R.M., Houten, T.A., Perry, J.H. (1994) Incidence of American foulbrood infections in feral honey bee colonies in New Zealand. N. Z. J. Zool. 21, 285-287

Higes, M., Raquel Martín, R., Meana, A. (2006) Nosema ceranae, a new microsporidian parasite in honeybees in Europe. J. Invertebr. Pathol. 92, 93-95

Higes, M., Martin-Hernandez, R., Garrido-Bailon, E., Gonzalez-Porto, A.V., Garcia-Palencia, P., Meana, A., del Nozal, M.J., Mayo, R., Bernal, J.L. (2009) Honeybee colony collapse due to Nosema ceranae in professional apiaries. Env. Microbiol. Rep. 1, 110-113

Hornitzky, M., Oldroyd, B.P., Somerville, D. (1996) Bacillus larvae carrier status of swarms and feral colonies of honeybees (Apis mellifera) in Australia. Austral. Vet. J. 73, 116-117

Huang, W., Jiang, J., Chen, Y., Wang, C. (2007) A Nosema ceranae isolate from the honeybee Apis mellifera. Apidologie 38, 30-37

Klee, J., Besana, A.M., Genersch, E., Gisder, S., Nanetti, A., Tam, D.Q., Chinh, T.X., Puerta, F., Ruz, J.M., Kryger, P., Message, D., Hatjina, F., Korpela, S., Fries, I., Paxton, R.J. (2007) Widespread dispersal of the microsporidian Nosema ceranae, an emergent pathogen of the western honey bee, Apis mellifera. J. Invertebr. Pathol. 96, 1-10

Kojima, Y., Toki, T., Morimoto, T., Yoshiyama, M., Kimura, K., Kadowaki, T. (2011a) Infestation of Japanese native honey bees by tracheal mite and virus from non-native European honey bees in Japan. Microb. Ecol. 62 , 895-906

Kojima, Y., Yoshiyama, M., Kimura, K., Kadowaki, T. (2011b) PCR-based detection of a tracheal mite of the honey bee Acarapis woodi. J. Invertebr. Pathol. 108, 135-137

Li, W.S. (1991) Quantitative declination of Chinese bee colonies and its causes. Chinese J. Ecol. 10, 50-53
Locke, B., Forsgren, E., Fries, I., de Miranda, R.J. (2012) Acaricide treatment affects viral dynamics in Varroa destructor-infested honey bee colonies via both host physiology and mite control. Appl. Env. Microbiol. 78(1), 227-235

Manning, R., Lancaster, K., Rutkay, A., Eaton, L. (2007) Survey of feral honey bee (Apis mellifera) colonies for Nosema apis in Western Australia. Austral. J. Exp. Agr. 47, 883-886

Muzaffar, N., Ahmad, R. (1991) Investigations on the seasonal incidence and control of the acarine mite Acarapis woodi (Rennie) in Apis cerana colonies in Pakistan. Pakistan J. Zool. 23, 139-144

Otis, G.W., Scott-Dupree, C.D. (1992) Effects of Acarapis woodi on overwintered colonies of honey bees (Hymenoptera, Apidae) in New York. J. Econ. Entomol. 85, 40-46

Roetschi, A., Berthoud, H., Kuhn, R., Imdorf, A. (2008) Infection rate based on quantitative real-time PCR of Melissococcus plutonius, the causal agent of European foulbrood, in honeybee colonies before and after apiary sanitation. Apidologie 39, 362371

Rosenkranz, P., Aumeier, P., Ziegelmann, B. (2010) Biology and control of Varroa destructor. J. Invertebr. Pathol. 103, S96-S119

Singh, R., Levitt, A.L., Rajotte, E.G., Holmes, E.C., Ostiguy, N., vanEngelsdorp, D., Lipkin, W.I., Depamphilis, C.W., Toth, A.L., Cox-Foster, D.L. (2010) RNA viruses in Hymenopteran pollinators: Evidence of inter-taxa virus transmission via pollen and potential impact on non-Apis Hymenopteran species. PLoS ONE 5 (12), e14357

Yanez, O., Zheng, H.Q., Hu, F.L., Neumann, P., Dietemann, V. (2012) A scientific note on Israeli acute paralysis virus infection of Eastern honeybee Apis cerana and vespine predator Vespa velutina. Apidol. 5, 587-589

Zhang, X., He, S.Y., Evans, J.D., Pettis, J.S., Yin, G.F., Chen, Y.P. (2012) New evidence that deformed wing virus and black queen cell virus are multi-host pathogens. J. Invertebr. Pathol. 109, 156-159 